\title{
Let's Raise a Half-Full Glass to the Zombie NHS: A Response to Recent Commentaries
}

\author{
Martin Powell*
}

*Correspondence to: Martin Powell, Email: m.powell@bham.ac.uk Copyright: $\odot 2016$ by Kerman University of Medical Sciences

Citation: Powell M. Let's raise a half-full glass to the Zombie NHS: a response to recent commentaries. Int J Health Policy Manag. 2016;5(2):147-148. doi:10.15171/ijhpm.2015.210

Received: 4 December 2015, Accepted: 14 December 2015, ePublished: 16 December 2015

$\mathrm{I}$ am very grateful that esteemed colleagues have taken the time to respond to my article, ${ }^{1}$ particularly engaging in the style of my original contribution. I will respond in terms of their level of agreement with me: to Rudolf Klein (largely right), Scott Greer (partly right), Ian Greener (right and wrong and right), and David Hunter (largely wrong).

First, with his persuasive prose and memorable phrases (eg, apocalyptic prophecies, premature obituaries, and inflationary rhetoric) Rudolf Klein improves my original article. ${ }^{2}$ The original article was worth writing if only to allow Klein to remind us of his 1983 phrase the longest death bed scene in British institutional history. He argues that drawing up a balance sheet is difficult because of the sheer complexity of the service, because there are wide variations in performance and because the notion of performance is itself contested and multidimensional. He states that the National Health Service (NHS) is once again in financial trouble is 'beyond doubt,' but sees a service creaking at the edges, but as yet far from terminal decline. While the NHS's fiscal future seems assured in the immediate future, its long-term prospects are a different matter.

Second, Scott Greer ${ }^{3}$ argues that the analytic problems raised might be disguising a larger issue of what exactly is the NHS? Like Klein, he agrees that the very multidimensionality of the NHS makes it hard to identify criteria and evaluative templates for its death. In his view, the NHS contains two key terms in its name: National and Service. While he argues that some current Conservative politicians dislike the "Service" in the NHS, Labour under Blair focused on the idea that the NHS should be free and universal at the point of service, leaving out public provision, and downplaying the Service aspect of the NHS in order to strengthen its National character. He states that 'the critics have a point' as the redistributive aspect of the NHS, couples insurance and redistribution in a way that social insurance schemes make complex and optional, and in a way that voucher schemes obscure, is in danger.

Third, Ian Greener' ${ }^{4}$ asks if I am right, and answers 'Yes and No. And Yes.' Like Greer, he asks what is the NHS, arguing that it is not just about principles, but also public provision ('ownership does matter') and the public service ethos. He states that data examining the extent of private provision in the NHS can get rather confusing, and that the public service ethos is important but rather elusive. He accepts that the public service ethos does not make problems magically go away, but argues that the public ethos is linked to availability, and that an NHS dominated by a contract-based ethos would be very different to the one we still have today. He concludes that, as in most eras, the NHS is both doing 'business as usual,' and in crisis. He asks if it is different this time, and responds that it probably is, as the NHS's very public model of healthcare, in terms of provision and ethos, is at risk of being undermined. Finally, David Hunter ${ }^{5}$ argues that, with a 'whiff of complacency' (I prefer glass half full), I overlook or understate the mounting body of evidence to suggest that 'the plot against the NHS' does have substance. Like Greener and Greer, he argues that the 'public realm' (public provision and the public service ethos) are important. Writing of 'institutional corruption,' the 'revolving door' between the NHS and corporate vested interests, he firmly nails his colours to the conspiracy ('indignant') rather than the cock-up ('incredulous') mast. He predicts that over time changes will create a tipping point. The NHS might continue in some capacity but it would be a hollowed out shell and a pale imitation of what was created 66 years ago. This will occur not with a bang but with a whimper, possibly before 2020 unless major changes occur.

A number of discussion points follow from these comments. First, all refer to the NHS in the present tense, suggesting that it still exists. A future 'tipping point' suggests that, even thoughts obituaries for the NHS have been posted for over 25 years, the NHS has not yet been killed or is a zombie. However, it is not clear how we can identify this tipping point. Some of the suggested criteria - such as principles, public provision, public service ethos, etc have already been given as the cause of death for many years. Were previous claims incorrect or premature? Moreover, I am tempted to see Hunter's 'whiff of complacency' and raise him a 'whiff of nostalgia'. As Greener points out, the NHS has not always lived up to the high ideals of its principles or public service ethos. It is important to differentiate the 'heart' argument of principles from the 'head' argument of practice and delivery. For example, how does the 'third sector' or 'social enterprise ethos' compare with the public service ethos? Second, Klein and Greer differentiate between those engaged in formal politics or are highly political, such as campaigning journalists or academics. Klein recognises that the strategies of opposition politicians and NHS professionals are understandable, if regrettable; the case of academics who echo them is a different matter, inviting 
the charge of 'trahison des clercs.' Third, while Klein and I tend towards 'cock up' (eg, demography, technology, contract specification. Private Finance Initiative $[\mathrm{PFI}]$ as a gravy train for private firms), the other commentators tend towards conspiracy. Finally, I have been accused of complacency before. ${ }^{6}$ I am delighted to be able to repeat the argument some 20 years later, and hope to do so again in another 20 years. In the meantime, let's raise a half full glass to the zombie NHS.

Ethical issues

Not applicable.

\section{Competing interests}

Author declares that he has no competing interests.

Author's contribution

MP is the single author of the manuscript.

\section{References}

1. Powell M. Who killed the English National Health Service?
Int J Health Policy Manag. 2015;4(5):267-269. doi:10.15171/ ijhpm.2015.72

2. Klein R. Rhetoric and reality in the English National Health Service: Comment on "Who killed the English National Health Service?" Int J Health Policy Manag. 2015;4(9):621-623. doi:10.15171/ijhpm.2015.105

3. Greer SL. Slow poisoning? Interests, emotions, and the strength of the English NHS: Comment on "Who killed the English National Health Service?" Int J Health Policy Manag. 2015;4(10):695697. doi:10.15171/ijhpm.2015.129

4. Greener I. Wolves and Big Yellow Taxis: How would be know if the NHS is at death's door? Comment on "Who killed the English National Health Service?" Int J Health Policy Manag. 2015;4(10):687-689. doi:10.15171/ijhpm.2015.124

5. Hunter DJ. The slow, lingering death of the English NHS: Comment on "Who killed the English National Health Service?" Int J Health Policy Manag. 2015;5(1):55-57. doi:10.1177/026101839601604702

6. Powell M. Granny's footsteps, fractures and the principles of the NHS. Critical Social Policy. 1996;16:27-44. doi: $10.1177 / 026101839601604702$ 